\title{
Perancangan Sistem Informasi Cuti Pegawai Pada Jakarta MRT Construction Managament Consultants Berbasis Website
}

\author{
Mambang Purwanto Purba ${ }^{* 1)}$, Hardianto ${ }^{2)}$ \\ 1) Program Studi Manajemen, Universitas Mohammad Husni Thamrin \\ 2) Program Studi Sistem Informasi, Universitas Mohammad Husni Thamrin \\ ${ }^{*}$ Correspondence Author: anto_Purba@yahoo.com, Jakarta, Indonesia \\ DOI: https://doi.org/10.37012/jtik.v6i2.323
}

\begin{abstract}
Abstrak
Jakarta MRT Construction Managament Consultants merupakan perusahaan yang bergerak di bidang jasa transportasi. Pada penelitian dilakukan analisa mengenai sistem cuti pegawai yang sedang berjalan saat ini. Dengan sistem cuti yang ada, ternyata pegawai masih sulit mendapatkan data yang akurat, dikarenakan pegawai yang akan mengajukan cuti tidak bisa mengetahui sisa cuti mereka. Untuk mengatasi masalah seperti ini, dirancang Sistem Informasi yang menengani proses cuti berbasis web, menggunakan bahasa pemrograman PHP dan MySQL.

Dengan adanya aplikasi cuti online ini, pegawai dapat menerima informasi yang lebih akurat tentang kepegawaian khususnya permasalahan cuti. Sistem cuti online yang dibuat mempermudah proses monitoring beserta proses pengajuan cuti. Dengan sistem cuti online, proses melihat riwayat cuti bisa lebih mudah dilakukan tanpa perlu bertemu dengan pihak HRD.
\end{abstract}

Kata Kunci: Sistem Informasi, Cuti, Website

\begin{abstract}
Jakarta MRT Construction Management Consultants is a company engaged in transportation services. In this study, an analysis of the current employee leave system was carried out. With the existing leave system, it turns out that employees still find it difficult to get accurate data, because employees who are going to apply for leave cannot know the rest of their leave. To solve this kind of problem, an Information System designed to address web-based leave processes, using the programming languages PHP and MySQL.

With this online leave application, employees can receive more accurate information about employment, especially leave issues. The online leave system that was created made it easier for the monitoring process and the leave application process. With an online leave system, the process of viewing leave history can be easier without the need to meet with HRD.
\end{abstract}

Keywords: Information Systems, Leave, Website

\section{PENDAHULUAN}

Perkembangan teknologi informasi berdampak pada semakin dibutuhkannya pengolahan data yang berfungsi untuk menghasilkan informasi. Perusahaanperusahaan yang ingin mengembangkan usaha dan mencapai sukses harus mengikuti era informasi dengan menggunakan alat pendukung pengolah data yaitu komputer.

Perusahaan Jakarta MRT Construction Management Consultants (JMCMC) adalah perusahaan yang bergerak dibidang jasa dan perusahaan JMCMC berada dibawah naungan Oriental Consultants Co. Ltd yang merupakan perusahaan dari Negara 
Jepang. Saat ini JMCMC bekerjasama dengan MRTJ dalam membangun Mass Rapid Transportation. JMCMC menyediakan tenaga-tenaga ahli atau expert dalam bidang transportasi untuk MRTJ. Perusahaan JMCMC didirikan pada tahun 2010 yang beralamat di Jl. Johar No.20, Menteng, Jakarta Pusat.

Perusahaan ini memiliki kendala dalam memonitoring cuti pegawai karena prosesnya masih dilakukan secara manual. Oleh sebab itu perlu dibuat perancangan sistem informasi cuti pegawai. Pengurusan cuti pada perusahaan JMCMC akan lebih dipermudah jika dapat memonitor data cuti pegawai menggunakan sistem berbasis website.

\section{METODE}

Metode pengembangan sistem yang gunakan adalah SDLC (System Development Life Cycle). Dalam Sebuah siklus SDLC terdapat 7 tahap umum. Siklus hidup pengembangan ini dapat diuraikan tahapan-tahapannya sebagai berikut :

1. Tahap Perancangan (Planning)

Pada tahap ini dilakukan feasibility study, lokasi waktu, dan cakupan dari aplikasi yang akan dikembangkan.

2. Tahap Analisa (Analysis)

Pada tahap ini akan diuraikan mengenai profil Jakarta MRT Construction Management Consultant, Identifikasi masalah dan solusi pemecahan masalah.

3. Tahap Perancangan (Design)

Tahap ini untuk menggambarkan panduan yang jelas mengenai pembuatan aplikasi yang dibuat secara detail.

4. Tahap Pengembangan (Development)

Pada tahap ini dilakukan pengembangan dengan menulis atau melakukan coding program-program yang diperlukan.

5. Tahap Pengujian (Testing)

Pengujiaan dilakukan terhadap aplikasi yang telah selesai ditulis atau setelah proses coding aplikasi selesai.

6. Tahap Impementasi (Implementation)

Implementasi dilakukan dengan menerapkan aplikasi yang telah selesai melalui tahap pengujian untuk digunakan oleh user. Pada tahap terakhir ini yang dilakukan adalah kegiatan-kegiatan untuk mendukung beroperasinya aplikasi yang akan dilakukan oleh admin. 


\section{HASIL DAN PEMBAHASAN}

Pada use case diagram dibawah ini, dapat dilihat logika dari sistem informasi pengajuan cuti pegawai Jakarta MRT Construction Management Consultants.

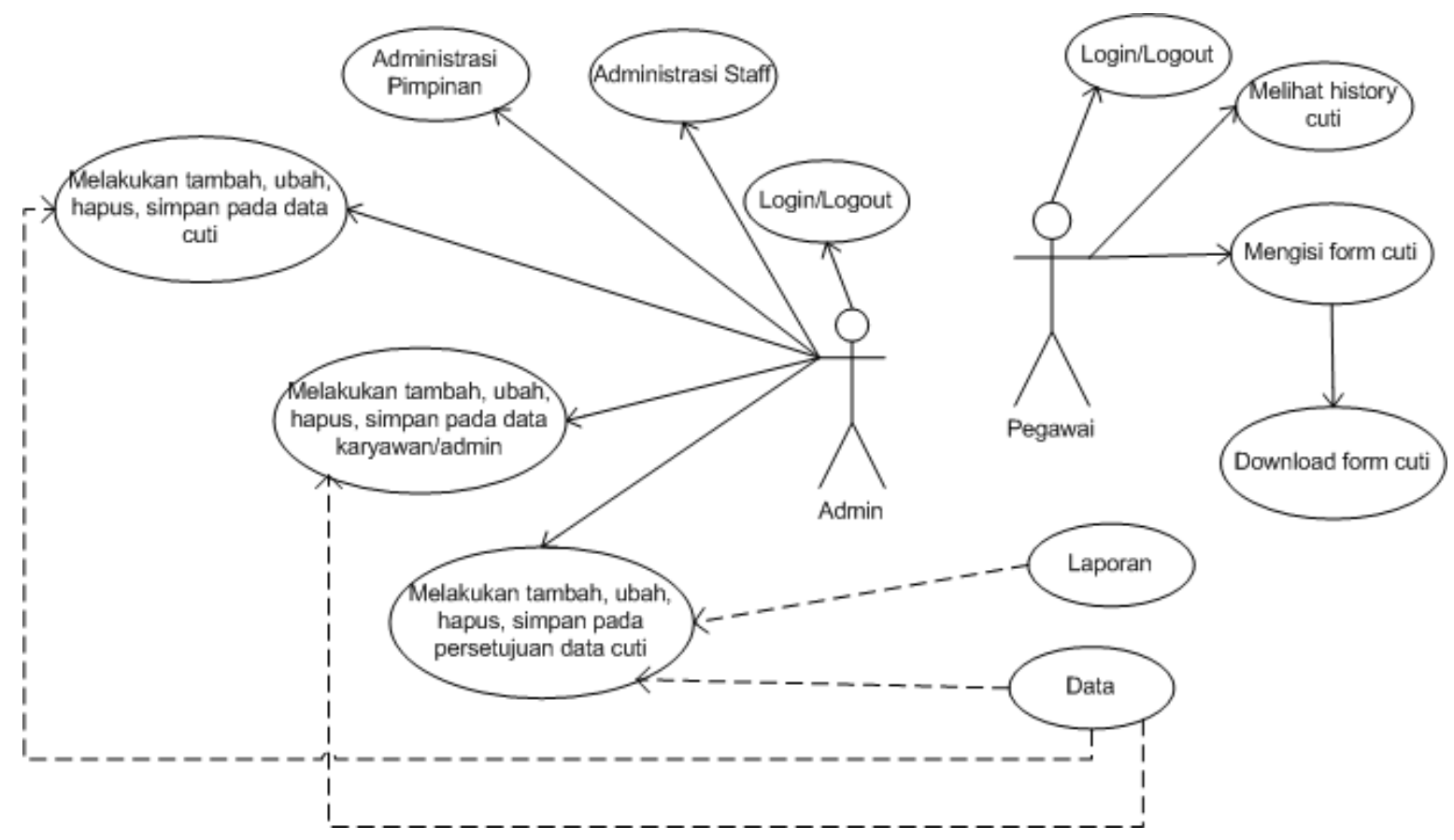

Gambar 1. Use Case Diagram

Activity Diagram memberikan gambaran bagaimana sistem berinteraksi dengan pengguna dan/atau dengan sistem lain. Berikut merupakan activity diagram dari sistem usulan pengajuan cuti pegawai Jakarta MRT Construction Management Consultants. 


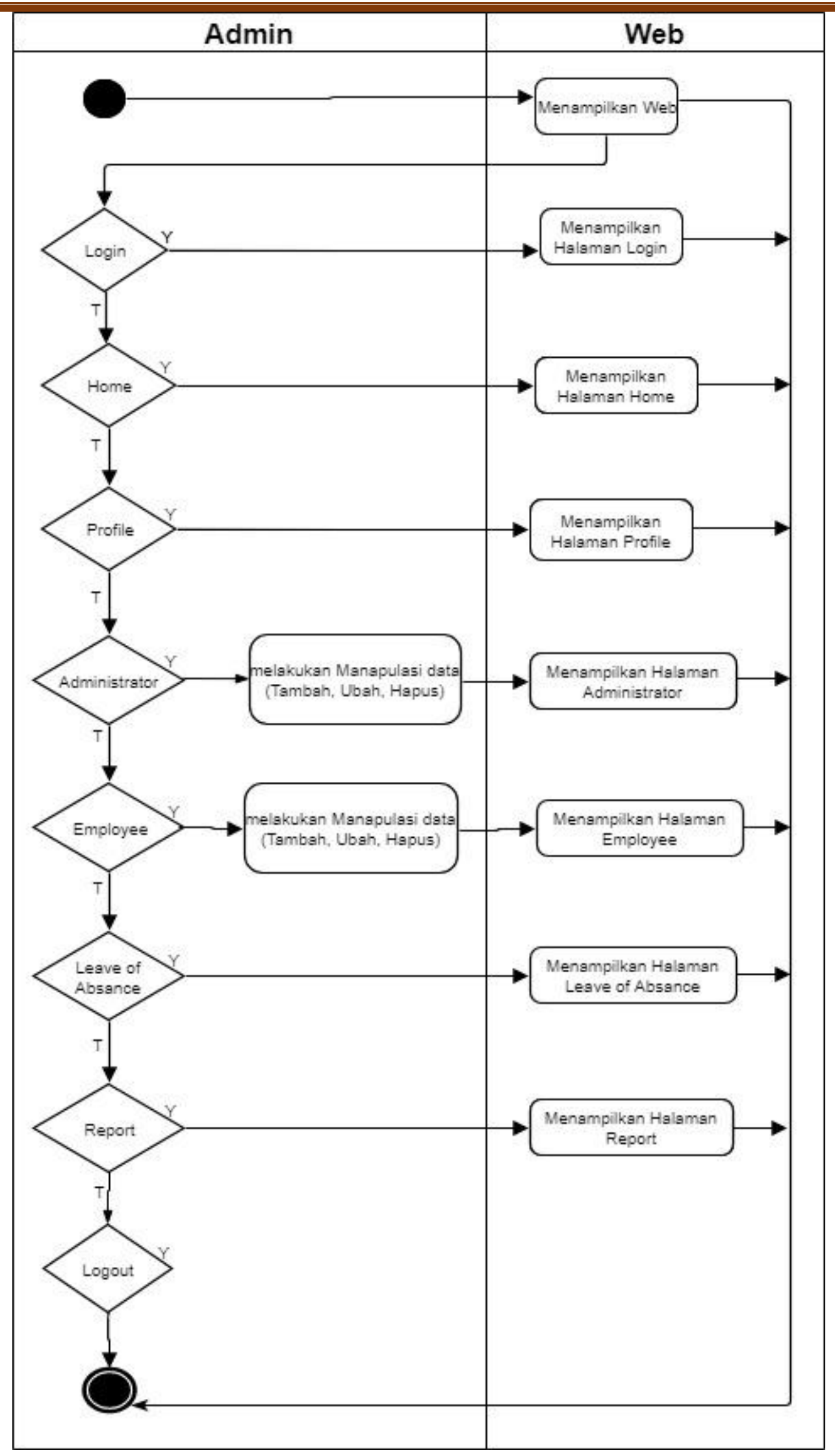

Gambar 2. Activiy Diagram Admin 


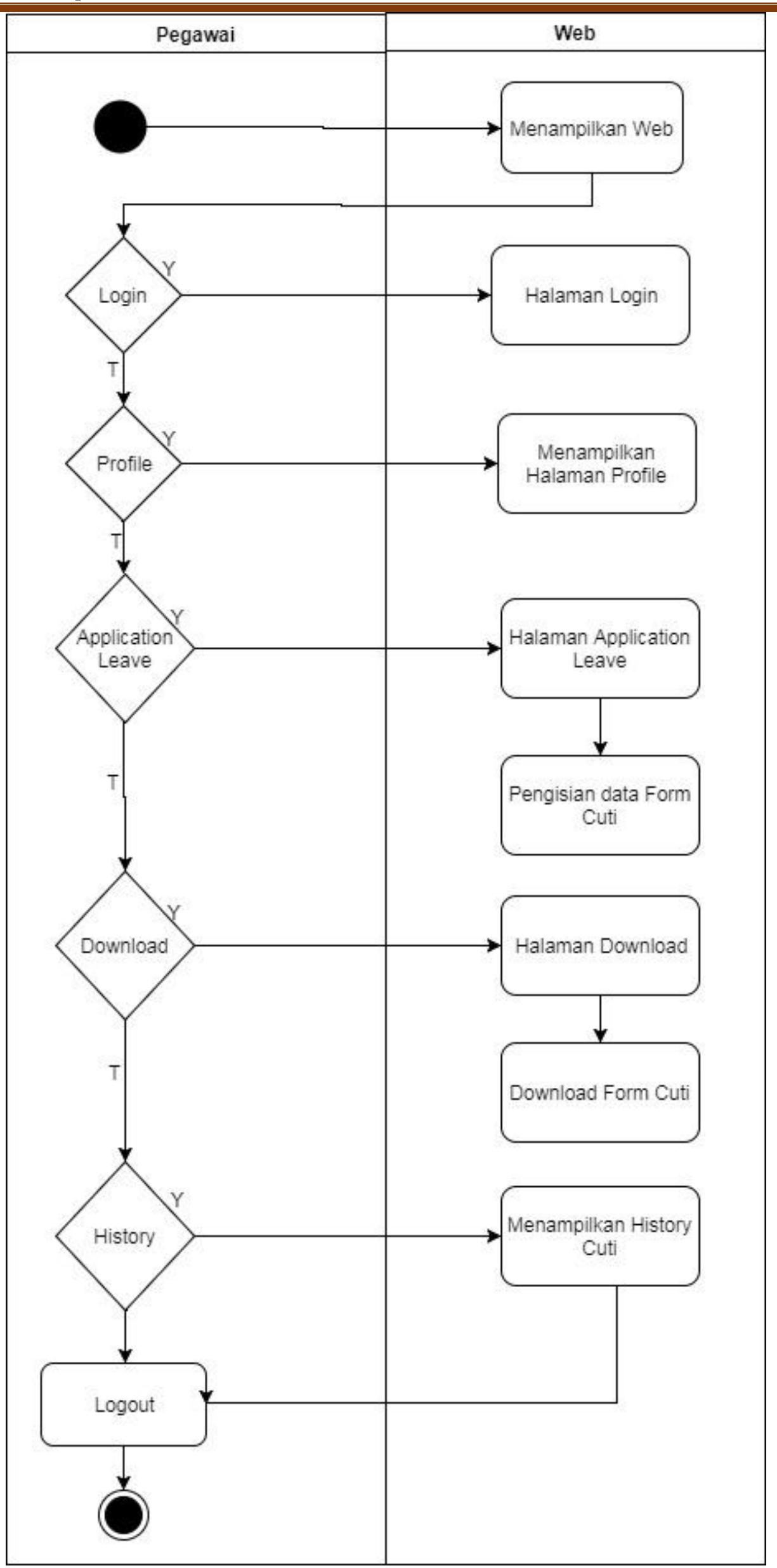

Gambar 3. Activity Diagram Pengajuan Cuti Pegawai 
Sequence Diagram (diagram urutan) adalah suatu diagram yang memperlihatkan atau menampilkan interaksi-interksi antar objek di dalam sistem yang disusun pada sebuah urutan atau rangkian waktu. Interaksi antar objek tersebut yaitu pengguna, display, dan sebagianya berupa pesan/message. Sequence diagram digunakan untuk menggambarkan skenario atau rangkaian langkah-langkah yang dilakukan sebagai sebuah respon dari suatu kejadian untuk menghasilkan output tertentu. Sequence diagram diawali dari apa yang men-trigger aktifitas tersebut, proses dan perubahan apa saja yang terjadi dan output apa yang dihasilkan. Berikut adalah sequence diagram yang ada pada program usulan.

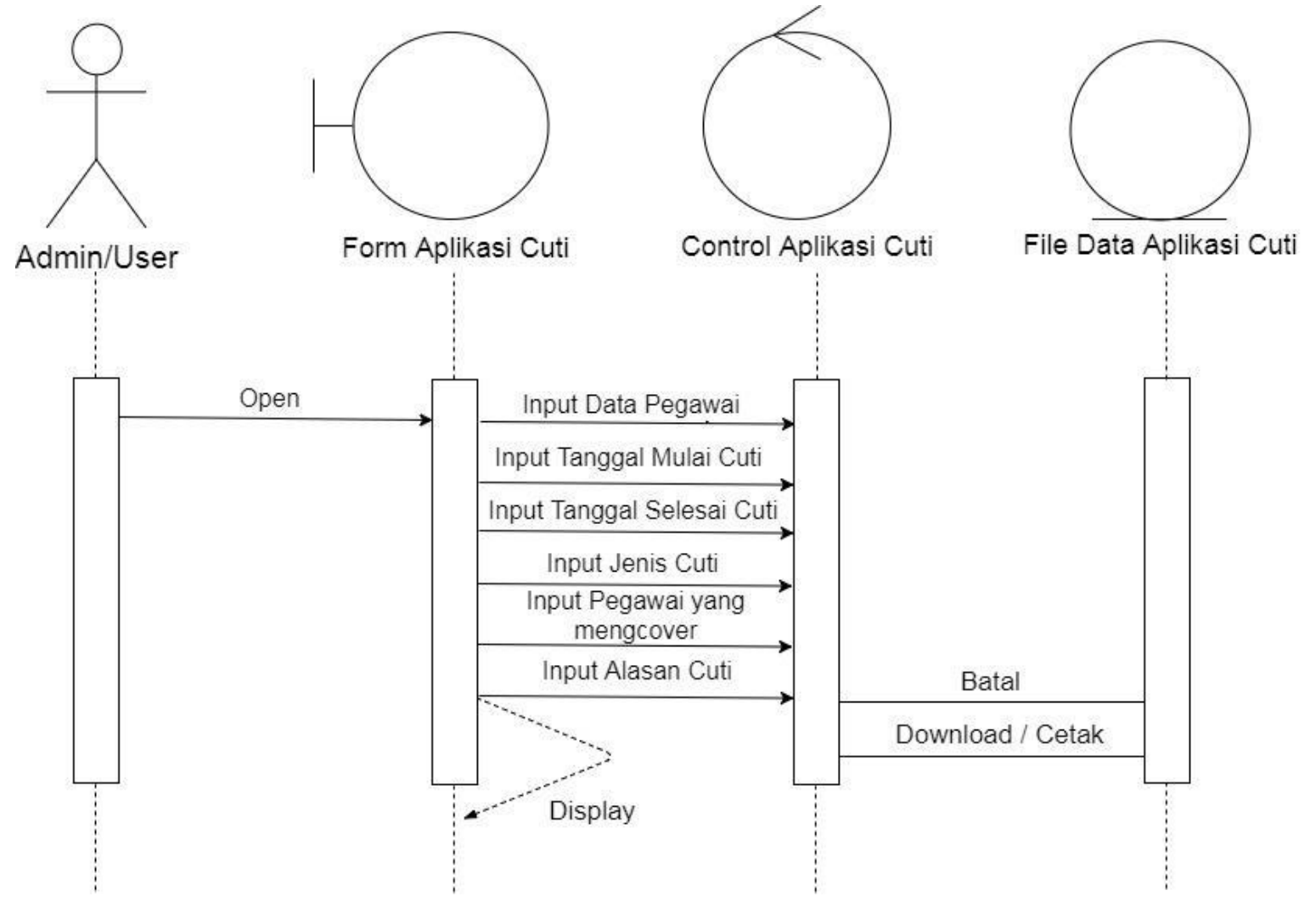

Gambar 4. Sequence Diagram Pengajuan Cuti

Class diagram adalah sebuah spesifikasi yang jika diinstansiasi akan menghasilkan sebuah objek dan merupakan inti dari pengembangan dan desain berorientasi objek. Kelas menggambarkan keadaan (atribut/properti) suatu sistem, sekaligus menawarkan layanan untuk memanipulasi keadaan tersebut (metoda/fungsi). Kelas diagram menggambarkan struktur dan deskripsi kelas, package dan objek beserta hubungan satu sama lain seperti containment, pewarisan, asosiasi, dan lain-lain. 


\begin{tabular}{|c|c|c|c|c|}
\hline Admin & \multirow[b]{3}{*}{$\stackrel{0 . *}{\longleftarrow}$} & \multirow{8}{*}{\begin{tabular}{|l}
\multicolumn{1}{|c}{ Pegawai } \\
Nik \\
nama \\
bagian \\
tempat_lahir \\
tanggal_lahir \\
alamat \\
jenis_kelamin \\
email \\
agama \\
no_hp \\
id_cuti \\
status_nikah \\
posisi \\
tgl_masuk
\end{tabular}} & \multirow{3}{*}{$\frac{1 .{ }^{*}}{0 .{ }^{*}}$} & \multirow{3}{*}{\begin{tabular}{|l}
\multicolumn{1}{c}{ Bagian } \\
id_bagian \\
nama_bagian
\end{tabular}} \\
\hline $\begin{array}{l}\text { Username } \\
\text { Password }\end{array}$ & & & & \\
\hline \multirow{4}{*}{$\begin{array}{l}\operatorname{login}(): \text { void } \\
\operatorname{logout}(): \text { void }\end{array}$} & & & & \\
\hline & \multirow[t]{4}{*}{$1 \ldots{ }^{*}$} & & & $\begin{array}{l}\text { update }() \text { : void } \\
\text { delete }() \text { : void }\end{array}$ \\
\hline & & & & Cuti \\
\hline & & & 1..* & $\begin{array}{l}\text { id_cuti } \\
\text { nama cuti }\end{array}$ \\
\hline \multirow{3}{*}{$\begin{array}{l}\text { id_pegawai } \\
\text { nama } \\
\text { bagian } \\
\text { tgl_masuk } \\
\text { cuti_tahunan } \\
\text { cuti_keperluan }\end{array}$} & & & $0 .{ }^{*}$ & \\
\hline & \multirow[t]{2}{*}{$0 .{ }^{*}$} & & & \\
\hline & & $\begin{array}{l}\operatorname{login}(): \text { void } \\
\operatorname{logout}() \text { : void } \\
\operatorname{view}() \text { : void }\end{array}$ & & $\begin{array}{l}\text { input(); void } \\
\text { update }(): \text { void } \\
\text { delete }() \text { : void }\end{array}$ \\
\hline input data cuti() : void & & & & \\
\hline
\end{tabular}

Gambar 5. Class Diagram 


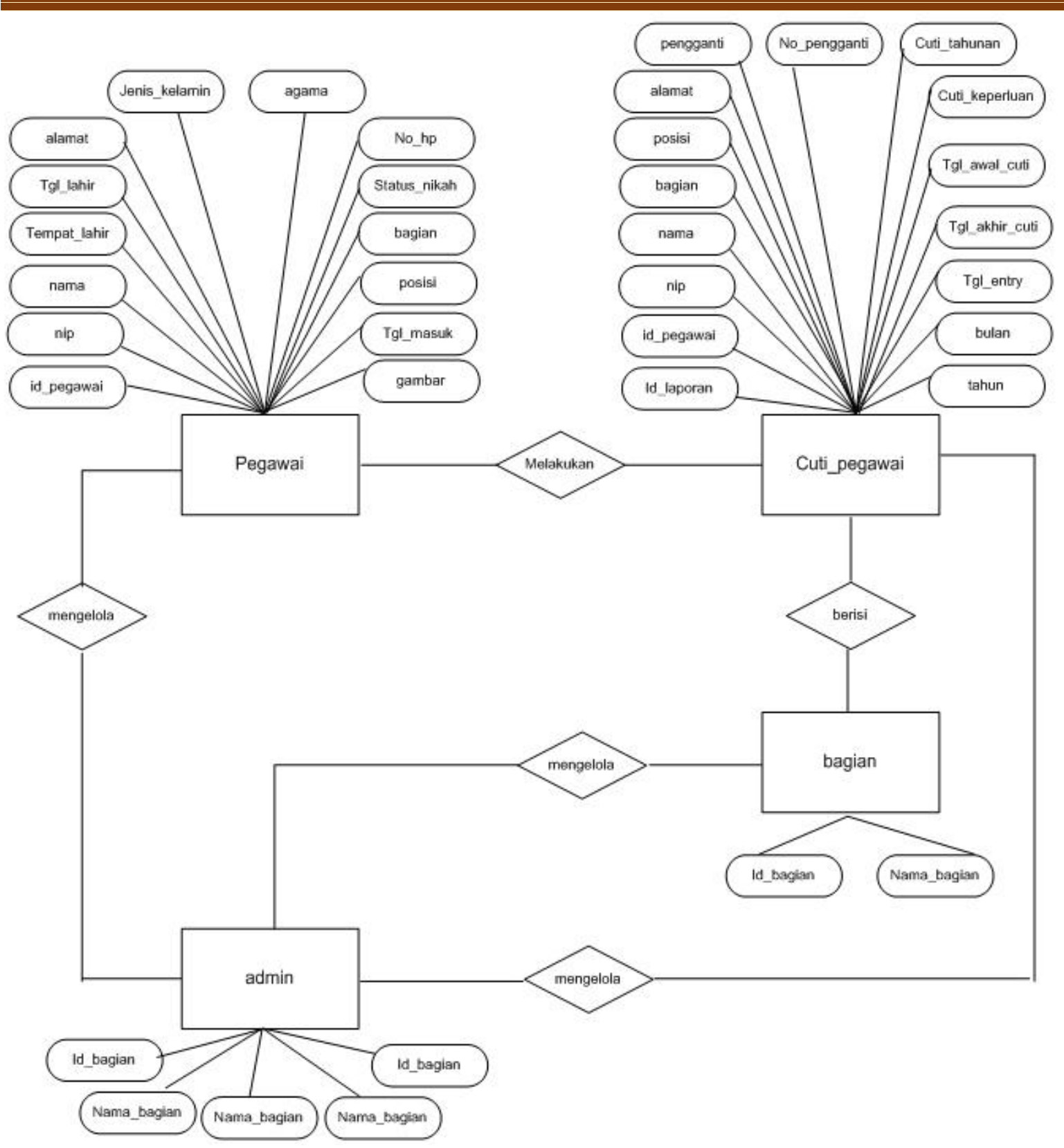

Gambar 6. Entity Relationship Diagram

Implementasi sistem merupakan kelanjutan dari kegiatan rancangan program dan dapat dipandang sebagai usaha untuk mewujudkan sistem yang telah dirancang serta merupakan tahap menginstal sistem supaya siap untuk diimplementasikan pada perusahaan. 

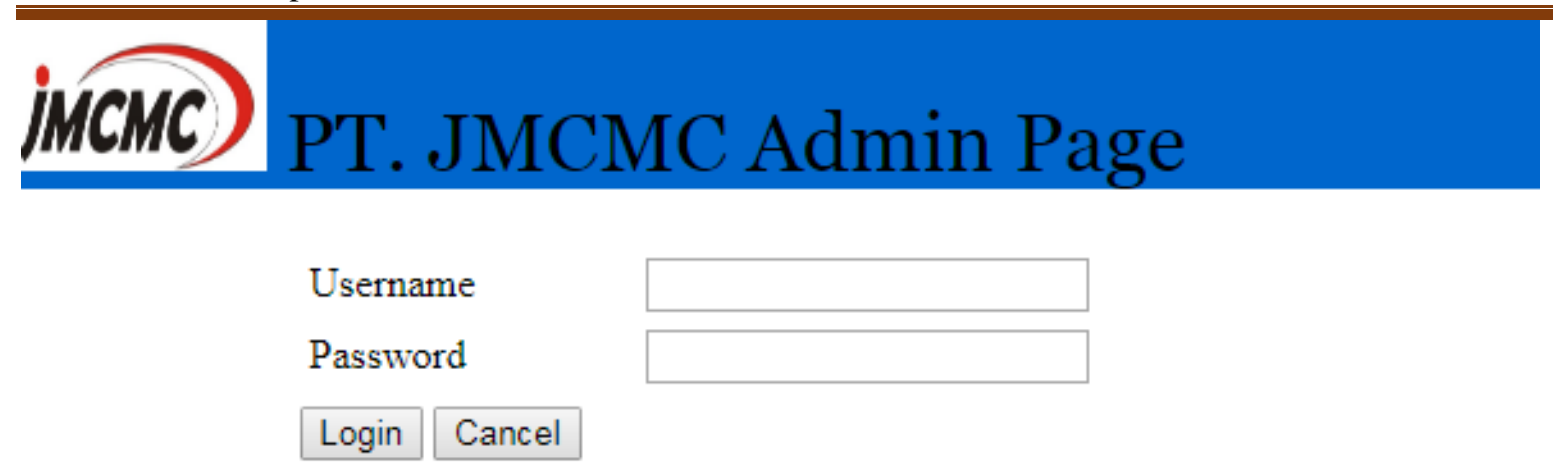

Login Cancel

Gambar 7. Tampilan Halaman Login Admin

\section{jMCMC}

$\square$ Home

\# Profile

(8) Administrator

\section{E -Leave Online}

Employee

Welcome Poppy

[8 Department

\# Leave of absence

\# Report

Gambar 8. Tampilan Halaman Home Admin

\section{IMCMC}

$\square$ Home

田 Profile

\section{PROFILE}

(6) Administrator

(8) Employee

8 Department

\# Leave of absence

표 Report
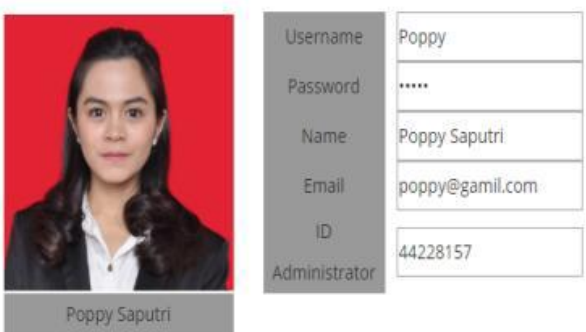

Gambar 9. Tampilan Halaman Profile Admin 


\section{jMCMC}

$\square$ Home
\# Profile
$\square$ Administrator
$\square$ Employee
$\square$ Department
Leave of absence
Report

\section{FIND DATA EMPLOYEE}

\section{Id Employess}

Find

View Report

\begin{tabular}{|c|c|c|c|c|c|c|}
\hline ID Employess & Name & Department & Work Started & Paid Leave & Special Leave \\
\hline 42788205 & Teguh Triyono & ENGINEER & $02 / 12 / 2016$ & 12 & 12 & $/ 1$ \\
\hline 78797032 & REIN VAN MANEN & EXPERT & $20 / 05 / 2015$ & 5 & & $/ \emptyset$ \\
\hline 14812550 & DESTI NURMANITA & STAFF & $01 / 01 / 2015$ & 3 & 4 & $/ \emptyset$ \\
\hline
\end{tabular}

Gambar 10. Tampilan Halaman Leave of Absence

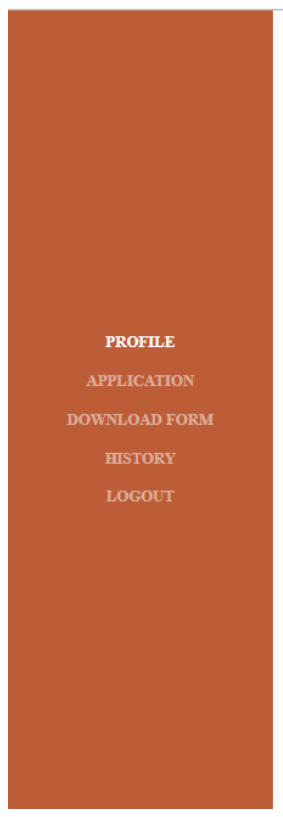

\section{EMPLOYEE PROFILE}

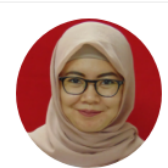

$\begin{array}{ll}\text { ID } & 14812550 \\ \text { EMPLOYESS } & \\ \text { NAME } & \text { DESTI NURMANITA } \\ \text { PLACE OF } & \text { JAKARTA } \\ \text { BIRTH } & \\ \text { DATE OF } & \text { 20/03/1989 } \\ \text { BIRTH } & \text { J1. Fatmawati 1 } \\ \text { ADREESS } & \\ \text { EMAIL } & \text { desti@gmail.com } \\ \text { MOBLE } & \text { 0862892273 } \\ \text { PHONE } & \text { STAFF } \\ \text { DEPARTMENT } & \end{array}$

Gambar 11. Tampilan Halaman Profile Pegawai 


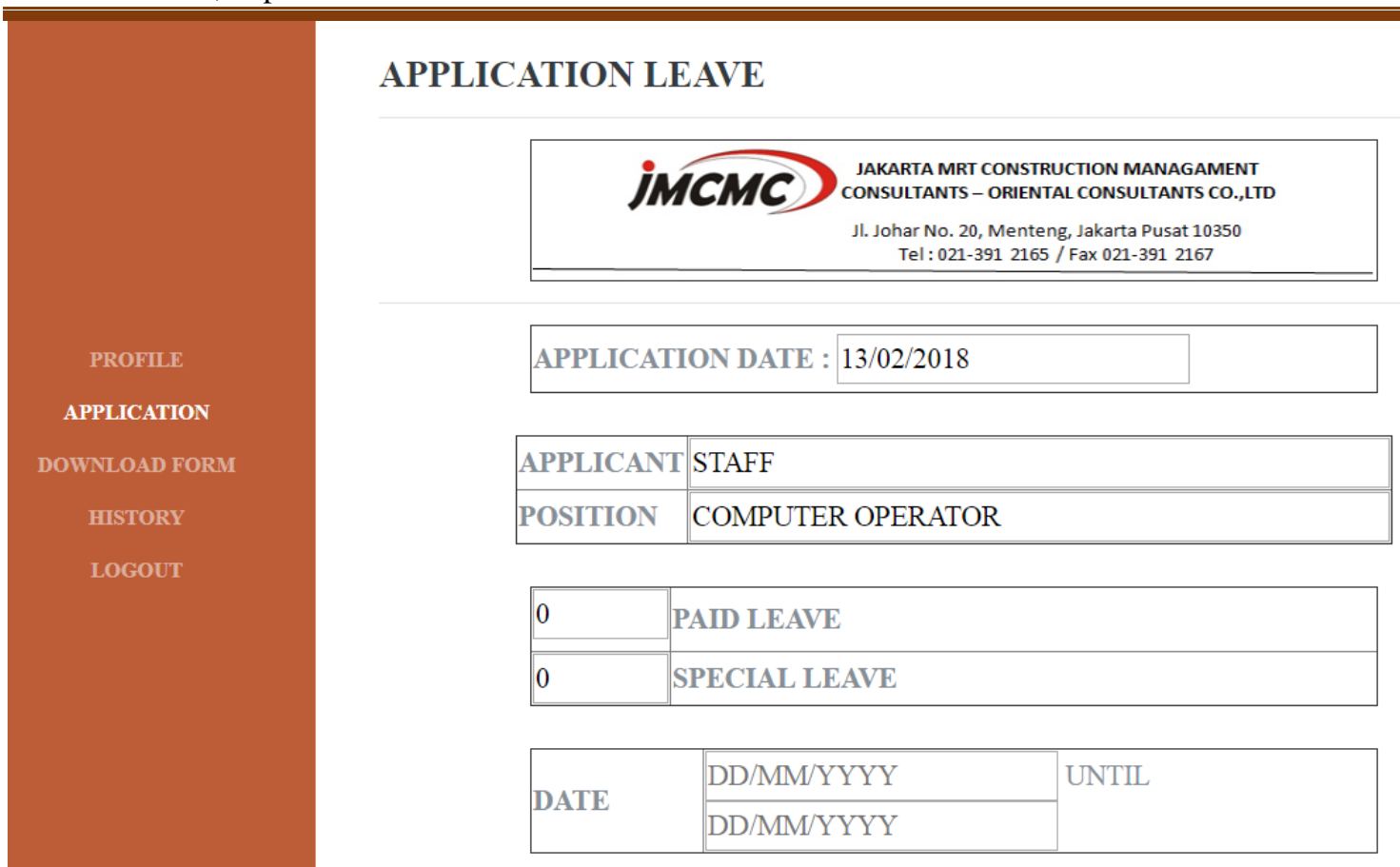

Gambar 12. Tampilan Halaman Application Leave Pegawai

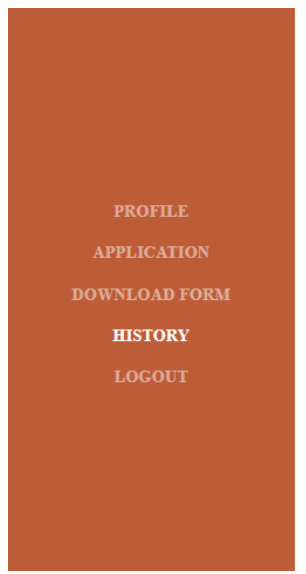

\section{HISTORY}

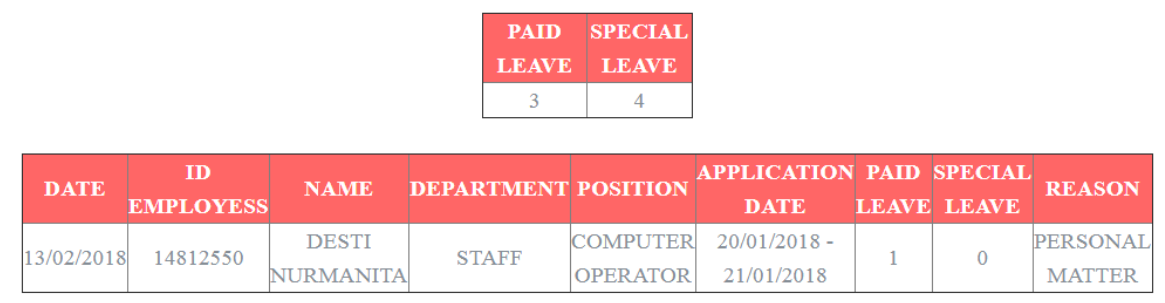

Gambar 13. Tampilan Halaman History Cuti Pegawai

\section{KESIMPULAN DAN REKOMENDASI}

Dari hasil penelitian dan pembuataan web yang ada pada penelitian, maka dapat disimpulkan beberapa hal sebegai berikut:

Dengan adanya aplikasi cuti online ini, pegawai dapat menerima informasi yang lebih akurat tentang kepegawaian khususnya permasalahan cuti. Sistem cuti online yang dibuat mempermudah proses monitoring beserta proses pengajuan cuti. Dengan sistem cuti online, proses melihat riwayat cuti bisa lebih mudah dilakukan tanpa perlu bertemu dengan pihak HRD. 
Guna meningkatan fungsi dari sistem cuti online sebagai pelayanan dan penyebaran informasi, maka pengembangan lebih lanjut yang dapat dilakukan antara lain:

Memperbaiki tampilan (interterface) dari sistem cuti online sehingga lebih menarik dan mudah digunakan. Memberikan sistem keamaan yang lebih bagus sehingga tidak mudah di salah gunakan oleh orang yang tidak bertanggung jawab.

\section{REFERENSI}

Rossa A.S dan M. Shalahuddin. 2013. Rekayasa Perangkat Lunak. Bandung: Informatika.

Enterprise, Jubilee. 2017. Otodidak MySQL Untuk Pemula. Jakarta : Elex Media Komputindo.

Raharjo, Budi. 2016. Modul Pemograman WEB (HTML, PHP \& MySQL). Bandung : Modula.

Nugroho, Bunafit. 2013. Dasar Pemograman Web PHP - MySQL dengan Dreamweaver. Yogyakarta : Gava Media

https://id.wikipedia.org/wiki/Adobe_Photoshop diakses pada tanggal 10 Januari 2018 pukul 21:25

Hendrawan, Hendrawan. 2017. http://ejournal.stikom-db.ac.id/index.php/mediasisfo/ article/view/211/198 diakses pada tanggal 30 Januari 2018 pukul 21:25 698 - 708. 